\title{
HZ. MUSA VE HIZIR KISSASI ÜZERİNE BİR DEĞERLENDİRME
}

\section{öz}

Kehf sûresinde sıra dışı olan üç kıssa anlatılmaktadır. Bu kıssaların ikincisi, sûrenin 60 ve 82. âyetleri arasında yer alan, Hz. Musa'nın ve Allah ü Teâlâ'nın kendisine rahmet ve ilim verdiği salih bir kul (Hızır) arasında gerçekleşen kıssadır. Kıssada yer alan üç hadise bu makalemizde ağırlıklı olarak ele alınmıştır. Bu üç hadise, günlük hayatta yaşadığımız olayları okumada bize nasıl bir bakış açısı kazandırabilir, bu bakış açısı manevî gelişimimize ne tür bir katkı sağlayabilir? Bu çalışmada mezkur soruların cevapları, başta Mevlânâ olmak üzere bazı ariflerin görüşleri esas alınarak ortaya konulmaya çalışılmıştır.

anahtar kelimeler

Kıssa, Hızır, Kehf, Hz. Musa.

\section{An Assessment on the Story of Prophet Moses and Khidr abstract}

There are three peculiarities stories which are unusual, are given in the Surah of Kahf. The second of these chapters, It is a story that takes place between Moses and a righteous servant (Khidr) whom Allah has given mercy and knowledge to him. The three incidents in the story are mainly addressed in this article. What 
kind of a contribution can these three perspectives contribute to our spiritual development, which can give us a perspective on the events we are living in everyday life? In this study, the answers of the questions were tried to be put forward based on the views of some of the people, especially Mevlana.

\section{keywords}

Story, Khidr, Kehf, Hz. Moses.

\section{Giriş}

Kur'ân-ı Kerim'in muhtevası içerisinde önemli yeri olan konulardan birisi de peygamberler, önemli tarihi olaylar ve geçmiş milletleri anlatan kıssalardır. Kıssa kavramı lügat anlamı itibariyle bir kimsenin izini sürüp ardınca gitmek, bir kişiye bir sözü beyan edip bildirmek, bir şeyi makasla kesmek, göğüs, göğsün başı ve ortası, göğüs kemiği gibi manaları taşımaktadır (Rağıb Isfahânî, trs: II, 523; Zebidî, 2004: XVIII, 98-101; Ergin, 2014: 225; Şengül, 1995: 44-51). Ancak bu manalardan baskın olan iz takip etmek manasıdır. Buna göre kıssalar, insanlar tarafindan takip edilmesi gereken güzel hasletler olarak kabul görmüştür (Kaya, 2002: 508).

Kıssaların hikmet ve ibret yönü ön planda olduğu için gerçek hikâyelere konu olan olaylar etkili bir üslupla anlatılmış, insanlığın benzer olaylarla karşılaşmasının her zaman mukadder olduğu hatrlatılmıştr. İnsanlık bu yaşanmış hayat hikâyelerinde kendini ve toplumu sorgulama imkânı bulmaktadır. Bu anlatımlar kişilerin ve toplumların yaşamı ve geleceği ile ilgili olarak vereceği kararlarda bir mihenk noktası görevini üstlenmektedir. Dolayısıyla Kur'ân kıssalarında verilmek istenen mesajı algılayabilmek, insanlığın kurtulması ve yaratıcıyı tanıması için önemlidir (Kılıç, 1998: 77-78). Diğer yandan Kur'ân-ı Kerim her zaman aynı idrak ve ilim seviyesine sahip insanlara hitap etmediği için, umuma verilen mesajı kolay anlamasına zemin hazırlayacak anlatım yöntemlerini tercih etmiştir. Bu yüzden Kur'ân teşbih, beliğ-modeli içinde yer alan bu nevi temsillere diğer edebi temsil şekillerinden daha fazla yer vermiştir (Sağlam, 1985: 10-11).

Kıssaların Kur'ân'daki manaları şu şekilde ifade edilmiştir:

1.Peygamberi teselli etmek ve onun irade ve azmini kuvvetlendirmek

2.Insanların ibret almalarını sağlamak (Yusuf 12/111; Kamer 54/ 5; Teğabûn 64/5).

Kıssalar temelde iki ana gayeyi ön plana çıkarmakla beraber, esasen Kur'ân'ın hedeflediği bütün maksatlara hizmet etmek için yer almışlardır. Bundan dolayı kıssalara geniş̧̧e yer verilmesinin birçok sebebi bulunmaktadır. Mesela, iman esaslarını ispat etmek ve bazı dini mevzuları ortaya koymak (Rabbih, 
1972: 89). Bütün semavi dinlerin asıllarının bir olduğunu ve Allah tarafindan gönderildiğini, bütün peygamberlerin İslam'ı tebliğ ettiklerini ve mü'minlerin tek bir ümmet olduklarını göstermek (Nedvî, 1954: 51). Bu gerçeğin tespit edilmesi ve vicdanlara yerleşmesi için, genellikle birkaç peygamber kıssası aynı sûrede peş peşe, az bir değişiklikle ve kendine has bir üslupla sunulur (Kutub, trs: 121-3). Enbiya sûresinin 48-92. Âyetlerini intiva eden bölümler bunun en güzel örneğidir (Ergin, 2014: 19- 23). Bu bölümde her bir peygamberin kıssası anlatılır ve son âyet bu uzun anlatımın asıl hedefini bildirir: "Muhakkak ki bu sizin ümmetiniz tek bir ümmettir. Ben de sizin Rabbinizim. O halde (başkasına değil) yalnız bana kulluk edin."

Bir diğer neden muhataplarının ders almalarını sağlamak, mü'minlerin ve inkârcıların durumlarını karşılaştırarak, Allah'ı ve âyetlerini inkâr eden toplumların başlarına gelen hadiselerin gözler önüne serilmesi, böylece muhatapların uyarılarak iyiye ve güzele teşvik edilmeleri ve peygamberimizle birlikte inananları manen güçlendirmek. Başka bir ifadeyle, Allahu Teâlâ’nın sonunda mü'minlere yardım edip onları zafere ulaştracağını, inanmayanların ise acı bir sonla yok olacaklarını açıklamakla $\mathrm{Hz}$. Peygamber'in ve ona inananların kalplerini etkilemeyi ve sağlamlaştırmayı hedefler. İşte bunun için peygamber kıssaları arka arkaya sunulmakta ve dini daveti tekzip edenlerin kötü akıbetleri anlatılarak en sonunda kıssaların zikredilmesindeki asıl maksat ortaya konmaktadır. Hud Sûresi bunun güzel bir örneğidir. Sûrede peygamberlerin tevhid mücadelesi ve kavimlerin başlarına gelenler tek tek anlatıldıktan sonra konuyu sonlandıran tek bir âyetle verilmek istenen mesaj muhataba sunulur (Kutup, trs: 125-6).

"Peygamberlerin haberlerinden kalbini sağlamlaştıracağımız (şeyleri) sana kıssa olarak anlatiyoruz. Bu sûrede de sana hak ve mü'minlere bir öğüt ve ihtar geldi." (Hud 11/120). Görüldüğü üzere burada da peygamber kıssası Peygamberimizin kalbinin sağlamlaştırılması yani mutmain veya teskin olmasının bir sebebi olarak gösterilmiştir. Aynı zamanda müminler için de bir öğüt ve bir ihtar oluşu bildirilmiştir.

Kıssalar nazil olduğu dönemden itibaren bugün de güncelliğini korumakta, bizlere hem öğüt vermekte hem de bizleri ihtar etmektedir. Bu bağlamda Kehf sûresinde geçen $\mathrm{Hz}$. Musa ile Hızır kıssası ve özelliklede bu kıssada yaşanan üç hadise bu çalışmanın temel konusu olarak ele alınmıştır. Bu üç hadisenin bize vereceği öğütler ve ihtarlar, hayatımızı anlamlandırmamızda ve şahsiyet yapılanmamızdaki katkıları, başta Mevlânâ olmak üzere bazı ariflerin görüşleri esas alınarak ortaya konulmaya çalışılmıştır.

Kehf sûresi Mekke'de özellikle müşriklerin Müslümanlara kaba kuvvet ve ekonomik baskı uyguladığı dönemde inmiştir (Albayrak 2003: 188-210). Bu dö- 
nemde inen âyetlere baktığımızda ise müşriklerin dünya hayatına bakışları ve âhiret inancını kabul etmedikleri bilgisi de yer alır (A'raf, 7/51; Casiye, 45/24; Mü'minûn, 23/33-38; Fatır, 35/5). Dolayısıyla bu kıssayı değerlendirirken nazil olduğu dönemde toplumun bu yapısını göz önünde bulundurmak hadiseleri anlamada önemlidir. Kıssada geçen salih kul, hadis kaynaklarında Hızır olarak isimlendirilmiştir (Buhârî, ìlim, 16) Biz de bu çalışmamızda salih kuldan "Hızır" diye bahsedeceğiz (Çelebi, 1998: 406-9; Ocak, 1990: 58-72; Yüce, 2011: 249259; Uludağ 1998: XVII, 410-1).

\section{Kur'ân'da Hz. Musa ve Hızır Kıssası}

$\mathrm{Bu}$ çalışmanın konusunu oluşturan üç hadiseyi değerlendirmeye geçmeden önce Hz. Musa'nın Hızır'la buluşmasına, Mevlânâ'nın ifade ettiği "Kevnî ihtiyaç" ilkesinden ${ }^{1}$ (Küçük 2009: 326-34) baktı̆̆ımızda Allah ü Teâlâ tarafindan Hızır vasıtasıyla Hz. Musa'ya ihtiyaç duyduğu ilmin kendisine ilka edildiğini düşünmemiz mümkündür. Hz Musa'nın hayatına Hızır'ın girmesi bir ihtiyaca binaendir. Bu ihtiyacın varlık sahnesine çıkması aynı zamanda Allah'ın Hz. Musa'ya bir ihsanıdır. Kevnî ihtiyaç ilkesi bugün bizim için de geçerlidir denilebilir.

"Her iki denizin birleştiği yere varınca, balığı unuttular. Balık denizde bir deliğe doğru yola koyulmuştu." Âyetteki bu balığın nasıl hareket ettiği konusunda ve balığın durumu hakkında birçok rivâyet bulunmaktadır (Kurtubi, 2000, $\mathrm{XI}$ : 61). Burada balık bir işaret olarak görülür. Bu işareti takip etmek sûretiyle $\mathrm{Hz}$. Musa buluşma noktasını bulmuştur. Buluşma yerini bulması için balığın canlanıp denize kaçması Allah'ın Hz. Musa'ya gösterdiği bir mucizedir (Kurtubi, 2000: XI, 62). Ancak, buluşma noktasına bu işaret olmadan da gidilebilirdi, elbette Allah'ın buna gücü yeterdi. Fakat mucizenin bile bir sebebe bağlı olarak gerçekleştiğini Allah ü Teâlâ burada bize göstermektedir. Zira bu âlem sebepler dünyasıdır. Kur'ân'da Hz. Meryem için" Nihâyet doğum sancısı onu (kuru) bir hurma ağacının dibine gitmeye mecbur etti... Hurma dalını kendine doğru salla, üstüne taze hurma dökülsün." (Meryem, 19/23, 25) buyrulur. Yani kuru hurma ağacından taze hurmanın dökülmesi sıra dışı bir olaydır. Ancak bu olayın gerçekleşmesi için Hz. Meryem'e hurma dalının kendine doğru sallaması istenmiştir. Görüldüğü üzere bu sıra dışı hadise de dalın sallanmasıyla, bir sebebe sarılmak suretiyle gerçekleştiriliyor. Yine Kehf sûresindeki diğer kıssalara bakt-ğımızda da sıra dışı diyebileceğimiz hadiselerin bulunduğunu görmekteyiz. Kehf sûresinde Zülkarneyn'in sahip olduğu sıra dışı güçten bahsederken sebeplere ittiba ettiği vurgulanmıştır. Bunun gibi misaller pek çoktur. Bu da bize gösteriyor ki Allah ü Teâlâ kulları ile bir mucize bile olsa, sebepler üzerinden iletişim kurmaktadır. Bundan dolayı gerek enfusî, gerek afakî olarak sebepler zincirini takip etmek suretiyle yaşadığımız hadiseleri daha sağlıklı yorumlayabilmemiz mümkün olabilecektir. 
"Derken kullarımızdan birini buldular ki biz ona katımızdan bir rahmet vermiş, katımızdan ilim öğretmiştik." (Kehf, 18/65). Âyetteki rahmet ifadesi; peygamberlik, nimet (Kurtubi, 2000: XI, 16), velâyet, uzun süre yaşamak gibi manalara gelmekle beraber çoğunluğa göre buradaki rahmet; vahiy, nübüvvet ve peygamberlik manasındadır. Kur'an-ı Kerim'in birçok âyetinde de bu manada kullanılmıştır (Yazır, 2009: V, 3260).

"...katımızdan ilim öğretmiştik." ifadesindeki ilim gayb ilmi olarak değerlendirilmiştir. Tasavvuf terminolojisinde Allah'tan vasıtasız olarak elde edilen ilimlere ilm-i ledün de denilmektedir (Razi, 1990: XXI, 148; Bursevî 1389, V, 270). Görüldüğü üzere bir tarafta "Sana doğru yol olarak öğretilen ilimden, bana da öğretmen için tabi olabilir miyim?" (Kehf, 18/66) demek suretiyle karşısındakinin sahip olduğu ilme talip olan $\mathrm{Hz}$. Musa ve diğer tarafta rahmet ve ilim verilen şahıs yani Hızır bulunmaktadır. Ancak Hızır'ın verdiği ilim uygulamaIı olarak anlatılan bir ilimdir ve Hızır'ın Hz. Musa'dan öncelikli olarak istediği şey sabırdır. Zira ilerleyen süreçte hiçbir şey göründüğü gibi olmayacaktır. Nitekim peygamberimiz de "Ya Rabbi eşyanın hakikatini bize göster" diyerek bizleri varlığın hakikatini anlama noktasına yönlendirmiştir.

Hz. Musa da: "inşallah beni sabırlı bulursun. Senin emrine karşı gelmem." (Kehf, 18/68) diyerek bu konuda sabır ve itaatini Allah'ın takdirine bağlamıştır (Razi 1990: XXI, 153). Hızır'ın Hz. Musa'dan istediği ikinci husus; zamanı gelene kadar soru sormamasıdır.

(Kehf, 18/70) Elmalı'ya göre ilimde soru sorma; ilmin temeli iken, bu durum ledün ilminde yasaklanmıştı. ${ }^{2}$ (Yazır 2009: V, 3264) Hz. Musa bu şartları kabul edildikten sonra bunun üzerine ikisi yola koyuldular. Böylece yolculuk başladı. Biz bu süreçte bahse konu olayları iki açıdan ele alacağız. Birincisi ayetleri okuduğumuzda ilk etapta anlaşılan zahiri manasının bize verdiği mesajlar. íkincisi; zahiri mananın altındaki mana sarmalları veya işârî manalarının verdiği mesajlar.

\section{A. Zahiri Mananın Verdiği Mesajlar}

Hz. Musa ve Hızır yolculuğunda üç tane olay bulunmaktadır. Birincisi; geminin delinmesi,

“... Nihâyet gemiye bindiklerinde onu deldi. Hz. Musa "halkını boğmak için mi onu deldin, gerçekten kötü bir iş yaptın, dedi." (Kehf, 18/71) ayette geçtiği şekliyle Hz. Musa geminin delinmesine böyle bir tepki verir. Hızır daha sonra bu olayın arka planını açıklar: "Deldiğim o gemi, denizde çalışan zavallılarındı. Onu kusurlu yapmak istedim. Çünkü onların ilerisinde, bütün gemileri zorla alan bir kral vardı." (Kehf, 18/79) Burada Hızır gemiyi kusurlu göstermek suretiyle güç odakları tarafindan ele geçirilmesinin önüne geçmiştir. Bu durum hayatı ve ha- 
diseleri yorumlamada bizlere bir ışık tutmaktadır. Zira bizim hayatımızda da sahip olduğumuz nimetler vardır ve bu nimetlerin çeşitli zarar verici güç odakları tarafindan tehlikeye maruz kalması söz konusudur. Kıssadaki tabloda güç odağı olarak kral zikredilirken bugün elimizdeki nimete el koymaya çalışan, iktisadî gücü olan, makam sahibi vb. güçlere muktedir veya gizli-aşikâr kıskançlık ve haset duyguları tahrik olmuş kişiler güç odağı olarak karşımıza çıkabilir. Bu durumda güç odakları karşısında kişinin sahip olduğu değerleri korumak ve gizlemek amacıyla stratejik bir savunma taktiği olarak kusurlu göstermesi gerektiği öğretilmektedir. Mevlânâ'nın aşağıdaki söylemleri, bize yol gösterecektir.

"Tavus kuşunun süslü kanadı, canının düşmanı olmuştur. Birçok hükümdarı da kuvvet ve azameti öldürmüştür. Masum ceylan göbeğindeki misk yüzünden avlanır, sahra tilkisine postu için tuzak kurulup derisi soyulur, Koca fil, dişi için öldürülür." (Mevlana 1993: I, b. 208-11). Bu beyitlerle sahip olunan nimetin taşıdığı potansiyel riskler nazara verilmiştir. Buna mukabil kurtuluşumuza sebep olacak sahip olmamı gereken ahlakî değerlerimiz için şöyle der: "Tavus kuşu gibi kanadına bakma, ayağını gör ki kötü gözler sana pusu kurmasın. Artık bundan sonra kendindeki hünerleri ve malı insanlara gösterme sakın." (Mevlânâ 1993: V, b. 498). Özet olarak diyebiliriz ki, Mevlânâ'nın ifadesiyle insanların çoğu insan yiyicidir (Mevlânâ 1993: II, b. 120), onlardan gelecek olan zararlara karşı maddi ve manevi olarak kişi uyanık olmalı ve tevazu içerisinde şükür ve kanaatle kendini koruma altnna alabilmelidir.

İkinci olaya geldiğimizde "Yine yürüyüp giderken bir oğlan çocuğuna rastladılar ve kul hemen onu öldürdü. Hz. Musa: "tertemiz bir canı öldürdün ha! Gerçekten sen çok kötü bir şey yaptnn!" dedi. (Kehf, 18/74) şeklinde yine sabredemeyip tepki gösterir. Bunun açıklamasını daha sonra Hızır şöyle yapmaktadır: " onun anne ve babası mü'min insanlardı. Bunun için onlara azgınlık ve inkâr bulaştırmasından korktuk. Rablerinin o çocuktan daha temiz ve onlara daha çok merhamet eden birini vermesini istedik." (Kehf, 18/ 80) Hz. Musa'nın "tertemiz cana nasıl kıydın " ifadesinden hareketle âyette geçen ğulam ifadesi birçok müfessire göre buluğ çağına ermemiş çocuk anlamında ele alınmıştır (Yazır, 2009: V, 3265).

Üçüncü olay ise; "Bundan sonra yürüyüp gittiler. Bir köy halkına vardılar. Onlardan yiyecek istediler. Köy halkı onları misafir etmekten kaçındı. Derken orada yıkılmakta olan bir duvar buldular ve onu Hızır doğrulttu. Bunun üzerine Hz. Musa: "isteseydin bunun ücretini alırdın." dedi (Kehf, 18/77). Bu hadisenin iç yüzünü ise Hızır şöyle açıklar: "Duvar ise şehirdeki iki yetim çocuğun idi. Altnda, onlara ait bir hazine vardı. Babaları da iyi bir kimse idi. Rabbin diledi ki, onlar büyüyüp akılları ersin ve Rabbinden bir lütuf olarak kendi hazinelerini çıkarsınlar. Ben bunu kendiliğimden yapmadım..." (Kehf, 18/ 82). 
Ikinci hadisede Hızır'ın masum bir çocuğu öldürmesi ilk etapta akla ters gelmektedir. Fakat Hızır, bu fiilin sebebini "Ben bunu kendiliğimden yapmadım..." diyerek Allah'ın iradesine bağlamak suretiyle bu duruma açıklık kazandırmıştır. Zira herkes için takdir edilen bir ecel süresi vardır. Bu da ancak Allah'ın takdiriyle sonlanmaktadır. Bunun yanı sıra Allah'ın mü’min kullardan olduğu zikredilen anne baba için hayrı istemesi, çocuğun ölmesiyle imtihan edilmelerine sebep olmuştur. Nitekim başka bir âyet bu durumun açıklayıcısı mesabesindedir. "işte, ondan kötülügü ve fenâlığı def' ettik. Doğrusu o bizim, ihlâsa erdirilmiş kullarımızdandır." (Yusuf, 12/24).

Üçüncü hadisede babalarının salih bir insan olduğu vurgulanmaktadır. Böyle bir babanın çocuklarına bıraktığı hazinenin Hızır’ın duvarı örmesiyle koruma altnna alması da Allah'ın bir lütfu olmaktadır. Hızır burada sebepler zincirinin bir parçası olarak karşımıza çıkmaktadır. Zulüm ve adaletsizlik ise insanların zahirî sebeplere göre verdiği hükümdür. Zira âyet-i kerimede "Allah kullarına zulmetmez"3 (Âl-i İmran, 3/117) buyrulmuştur.

Bu iki hadisenin oluşumunu Mevlânâ'nın bildirdiği âlemde carî olan kevnî adalet ilkesinin tecellisi olarak görmemiz mümkündür. Çünkü kevnî adalet ilkesi, kişinin yüzeysel bir bakışla algıladığı sebepler dairesinde cereyan eden mantıki bir adalet sistemi olmayıp paradoksal bir özelliğe sahiptir. Buna göre adalet icrası, bütünüyle âhirete bırakılmayıp, insan yaptıklarının karşılığını dünyada da görmektedir. Sünnetullah gereği, kişinin yaptıkları kaydedilerek, ona uygun bir karşılık karşısına çıkacaktır. Ancak bu dünya suretler âlemi olduğu için bir şeyin sureti ile manası arasındaki ilişkinin gerçek mahiyeti, suretin manayı perdeleyen işlevi nedeniyle görünmez. Bu yüzden yapılan bir eylemin manası, bu suretler âleminin esası olan manalar âlemine hemen doğmasına rağmen, suretler âleminde o mana, peyderpey ve dolaylı olarak müşahede edilmektedir. Bundan dolayı insan herhangi bir iş yaparken onun doğuracağı manayı düşünerek hareket etmesi gerekmektedir (Küçük, 2009: 305-9). Çünkü Allah her şey için bir sebep yaratmıştır ve bu sebeplere tâbi olmamızı istemektedir. Nitekim "Ona her şeyden bir sebeb verdik." (Kehf, 18/84) âyeti bize sebeplere yapışmamız gerektiğini bildirir. Ancak meselenin zahiren görünen boyutu ile birlikte zaman diliminden dolayı direk fark edemediğimiz boyutunu da sebepler dairesi içine almak gerekmektedir. Esasen kevnî adalet ilkesinin kilit noktasını, görünen sebeplerin ardındaki vâkıf olunamayan sebepler oluşturmaktadır.

Bu bağlamda Mevlânâ şöyle der:

"Kıyamet gününden evvel herkese layığını verir.

Daima kendi ahvalini gözet.

Adalette bulundun mu gönül huzurunu gör, zulümden sonra da vicdan azabını." (Mevlana 1993: VI, b. 4528-32). 
Bu beyitlerde de ifade edildiği gibi, sadece âhirette değil bu âlemde de yaptıklarımıza bir karşılık verilmektedir. İyilik istiyorsan iyilik, kötülük istersen kötülük görüyorsun. İmtihanın gereği yaptığı iyilik veya kötülük hemen karşılı bulmuyor ve aynı cinsten değil. Çünkü maddi âlemde insanın yaptığı her işe gayb âleminde bir sûret verilmekte ve o sûret maddi âlem düzleminde bulunan insanı etkilemektedir. Ancak yapılan iş ile hissedilen etki birbirine benzemediğinden insan aradaki ilişkiyi anlayamamaktadır ${ }^{4}$ (Jung, 2015: 66- 67). Başka bir ifadeyle hayatta yapılan bir kötülük veya iyiliğin karşılığı, sahibinin idrak edemeyeceği ve aradaki irtibat kestiremeyeceği bir başka açıdan kişinin karşısına çıkmaktadır. Adaletin direk olmayan bu işleyişi, yine bu âlemin imtihan âlemi olmasıyla bağlantılıdır (Küçük, 2009: 311-13). Dolayısıyla Hz. Musa sûretteki amellerin gayb âlemine yansıyan manalarındaki bağlantıyı müşahede âleminin ölçü ve anlayışına göre değerlendirmeye çalıştı̆̆ için Hızır’ın tutum ve davranışlarını algılamada zorlanmış ve sabırsızlık göstermiştir (Kasaboğlu, 2006: 66). Hızır ise sûret ve gayba yansıyan manayla bir bütün olarak baktı̆ı için hadiselere kendinden emin bir insan tavrını sergilemektedir. Zira bütün bunların arkasındaki en önemli fail ise Allah ü Teâlâ'dır. " ..Hiç birini kendi görüşümle yapmış değilim..." 82. âyetiyle, Hızır’ın yaptıklarını bazen kendine bazen Allah’a izafe etmesini göz önünde bulundurursak bu hadiselerin Allah'ın izni, ilmi ve iradesiyle gerçekleştiği ve Hızır’ın bu ilahi planın bir parçası olduğu görülmektedir (Albayrak, 2003: 197).

Neticede ilk etapta şeraite mugayir ve mantık dışı gelen, anlaşılması zor, son iki hadiseyi kevnî adalet ilkesini esas alarak değerlendirdiğimizde daha geniş ve tutarlı bir bakış açısına kavuşmamız mümkün olabilecektir. Bu durumda kaderini, cüz'i iradesini iyi veya kötü yönde kullanmak suretiyle kendi çizen insanın sebepler silsilesini çözebilmesi zordur, kevnî adalet ilkesinin bizim lehimizde gerçekleşmesi için nasıl bir duruş sergileyebiliriz?. Bu noktada istiğfar ve tevbenin, kötüye meyletmede engel olucu bir sebep olması, duâ ve tevekkülün de hayra meyletmede yapıcı bir unsur olması, yine Allah'ın ilâhî kanunları çerçevesinde önemli bir yere sahiptir. Yani hâdiselerin ve varlığın bize göre sır olan hakikatine vakıf olamadığımız için, irademizi en güzel şekilde kullanabilme adına, bir taraftan tevbe halinde diğer taraftan duâ, tevekkül ve teslimiyet halinde olmak gerekmektedir. Çünkü insan günahlarının, hatalarının farkına varıp itiraf ederek pişman olursa, Allah'ın affina müstahak olur. Diğer taraftan kul, kulluğun özü olan duâya yapışır, O’na dayanır ve güvenirse, Allah o insan için hayrı takdir ederek lütufta bulunur. Böylece, kendi kaderini kendi çizen insan tevbeistiğfar, duâ ve tevekkül esaslarına yapıştı̆ı sürece, Allah'ın lütuflarına mazhar olarak yine kendi kaderini kendi çizecektir (Yılmaz 2014: 257). 


\section{B- Hadiselerin İşârî Yorumuna Dair Bazı Ariflerin Görüşleri}

Şimdi kıssadaki âyetlerin zahiri anlamlarından hareketle mana katmanlarına dair ariflerin görüşlerini ele alalım:

İbn Arabî görünüşte kötü, gerçekte iyi olan hadiselerin Hz. Musa'nın hayatında pek çok kez geçtiğine dikkatleri çeker. Bunların başında, nehre bırakılmasının görünüşte yok olmaya işaret etmesi gelir. Aslında olayın gerçek anlamı öldürülmekten kurtulmadır. Suya bırakılmak görünüşte yok oluşu göstermektedir, ancak anneye böyle hareket etmesini ilham eden bizzat Allah't. $\mathrm{Hz}$. Musa'nın suya bırakılması firavundan kurtulmasının yolu olmaktaydı. Nitekim annesi, oğlunu suya bıraktıktan sonra bir dinginlik ve huzur hissetmiştir. İbn Arabîye göre annenin bu hissiyat sadece hakikatte değil görünüşte de bir kurtuluş umudu içermektedir (ibnü'l-Arabî, 2013: 500).

İbn Arabî'ye göre Hızır’ın gösterdiği olaylar Hz. Musa'nın daha önce kendisinin yaşadığı olayların görünümünden ibarettir. Nitekim Hz. Musa tanımadığı kimseler için kuyudan ücretsiz su çekmişti. Bu hadisenin benzerini Hızır'da gördüğünde tepki gösterdi; Hızır'ın ebeveynine bir iyilik olarak Allah'ın emriyle öldürdüğü çocuk da, kıptideki hikmeti Hz. Musa'ya öğretmenin yoluydu. Gemiyi tahrip etmesi ise görünüşte tehlike ve yok olmayı içeren sandala konulup nehre bırakılmasının bir benzeriydi. Böylece Hızır, Hz. Musa'nın yaşadığı bir takım olayları kendisine göstermiş ancak Hz. Musa bunların hepsine tepki göstermişti. (ibnü'l- Arabî, 2013: 501).

İbn Arabî’nin yorumlarından hareketle diyebiliriz ki, Hz. Musa'nın yaşadığı olayların onun üzerindeki psikolojik etkisinin ve bilinçaltında oluşturduğu olumsuz kayıtların, Hızır'ın gösterdiği olaylarda anksiyete oluşturduğu ve tepki verdiği görülmektedir. $\mathrm{Hz}$ Hızır'la yaşadıkları Hz. Musa'nın bilinçalt korku ve endişeleriyle yüzleşme imkânı sunmuştur. Böylece Allah Hz. Musa'ya çocukluk ve gençliğinde yaşadığı imtihanların iç yüzünü, Hızır'la yaptığı arkadaşlıkta göstermiş olmaktadır. Dolayısıyla Hızır'la arkadaşlıkları Allah'ın Hz. Musa'ya özel bir lutfudur. Bir nev'i Allah'ın takdiri üzere Hızır, Hz. Musa'da bilinçalt düzenlemesi yapmıştır denilebilir. Zira Allah onun geçmişinde yaşadıkları bu olaylardan dolayı içinde yaşadığı ezikliğin gereksiz olduğunu göstermek ve suçlu olmadığını bildirmek istemiştir. Bütün bunlar bize göstermektedir ki, hayatımızda yaşadığımız her şey bir anlam örgüsü içerisinde gerçekleşmektedir.

İsmail Hakkı Bursevî’ye göre bu kıssadaki üç hadise insandaki kötü hallerin sembolüdür. Birinci hadisede geçen gemiden maksat, kişinin vücudu; gemiye zorla ele geçirmek isteyen kral, nefistir. Çocuğun öldürülmesi, nefsin heva hevesinin koparılıp atılmasıdır. Nefs bedeni ifsad etmeye, ruh ise ıslah etmeye çalışmaktadır. Hakk'ın hâkim olması için ruhun, nefs ve şehvet gibi yol kesici haramilere engel olması gerekir. Duvarın altndaki hazinenin sahibi olan yetim 
ise, ilahi sırlarla dolu olan kalptir. Hakk'ın gizli hazineleri, kalb tasviye edilip ehil olana kadar saklanmalıdır (Bardakçı 1998: 101; Bursevî, 1997: I, 459). Hızır’ın yetim çocuklara ait olduğu söylenen hazineyi korumak için duvar örmesini Bursevî ilahî sırlarla dolu olan kalbi hazineye benzetir. Dolayısıyla her insan da kendinde meknuz olan ilahî cevheri barındıran hazine mesabesindeki kalbi dış ve iç düşmanlardan koruyabilmelidir. Bu manayı te'yid sadedinde Mevlânâ sadece kalbi değil, bir bütün olarak insanı bir altın madenine benzetir ve modern asırda yaşadığımız tehlikelere karşı bizde farkındalık oluşturacak söylemlerde bulunur:

insanlık yolunun her tarafi kanla ıslanmış;

Dikkat et de kayma!

Bu zamanda insan çalanlar, altin çalanlardan daha fazla.

Duyarsın; hırsızlar sadece malı değil, aklı da çalarlar.

Hırsızlar altın peşinde koşuyor;

Sen de altin madenisin, kendinden habersiz olma!.

Sen uğraş da kendini bul;

Kendindeki gizli hazineyi araştır! Kendini bul;

Bul ama dikkatli ol, kendini çaldırma!

Bu Hak yolunda açıkgöz bir hırsız pusu kurmuş, seni bekliyor.

Bu hırsıza dikkat et de kendini çaldırma! (Mevlânâ 2000, I, 409).

Bu beyitlerde ifade edildiği üzere insan kendisi bir hazine bu hazineyi gerek iç gerek dış düşmanlardan Hızır misali koruması gerekmektedir.

Niyazî Mısrî ise bu üç hadisenin bir yönüyle genel, bir yönüyle özel olduğunu ifade eder. Genel oluşu, dünyada bu tür olayların her zaman meydana gelebilir olmasıdır. Yani fakirlerin gemileri/ malları, güç sahibi yöneticiler tarafindan her gün çalınıyor ve kıyamete kadar da çalınmaya devam edecektir. Çocukların, anne karnında bile olsa her gün binlercesi zaten öldürülüyor ve kıyamete kadar da öldürülecektir. Yine her gün altında define gömülü nice duvarlar yıkılıyor ve yıkılmaya da devam edecektir. Yani bu hadiseler her zamanda ve her yerde vuku bulabilecek şeylerdir.

Özel oluşu ise Hz. Musa'ya has olup ona ders vermek maksatlıdır ve enfüsîdir. Hızır bu şekilde bütün gemilere sahip çıkmaz. Yine aynı şekilde salih anne babaya isyan edecek çocuk çoktur. Hızır onların hepsini öldürmez. Yine bu devirde yer altında gömülü pek çok hazine vardır. Hızır onların hiç birinin üzerine duvar inşa etmez (Mısrî Süleymaniye Ktp: no: 3346, vr. 41b; Cebecioğlu, 2016, 1: 56 -8; Özler, 2004: 112). 
Niyazî Mısrî’ye göre dışarıdaki çocuk sevgisi kişideki makam sevgisine karşılık gelmektedir. Makam sevgisi, -çocuğa olan sevgi- silinip yok edilebilinirse insan o zaman azgınlıktan kurtulabilmektedir. Aksi halde çocuk sevgisine -makam sevdasına- düşen kişi, harama düşmekten ve zulüm yapmaktan kurtulamamaktadır (Mısrî Süleymaniye Ktp: no: 3346, vr. 46a- 46b; Cebecioğlu 2016: 73). Niyazî Mısrî de bu minvalde kıssada çocuğun öldürülmesi hadisesini sembolik anlam kazandırarak hubb-ı cahın izalesi olarak değerlendirir. Cebecioğlu bu sembolik anlamdan hareketle şöyle bir çıkarımda bulunur: " Hepimiz bir şekilde makam sahibiyiz,. Mesela babayız, aile reisiyiz; akrabalarımızın yaşça küçük olanlarının büyüğüyüz; bir dernek veya vakıf başkanıyız yâda bir memurlukta belli bir işin yürütülmesiyle görevliyiz; abiyiz, anneyiz, ablayız, bakanız, zenginiz, hakimiz, valiyiz, komutanız, öğretmeniz, müdürüz, imamız, şeyhiz, halifeyiz vs. yani hepimiz bir şekilde bu türden makamların sahibiyiz. Bulunduğumuz makamların hakkını verebiliyor muyuz? Acaba makamlarımız zulme ve harama girmeye yol açıyor mu? (Cebecioğlu, 2016: 73).

Demek ki, makam sahibi olmak problem değildir. Aksine işin tabiatında olması gerekendir. Sorun ise makam sevgisini putlaştiracak derecede merkeze alıp o sevgiden hareketle insanlara zulmetmek ve haksızlık yapmaktır.

Niyazi Mısrî’nin yorumlarına göre âyetler üzerinde tefekkür ederken biri afakî, diğeri enfüsî olmak üzere iki boyutu göz önünde bulundurmak gerekmektedir. Bu kıssadaki ayetleri de okurken bizdeki hem afaki boyutu ve hem de enfusî yansımalarını görüp kendimizi yapılandırmamız gerekmektedir. Mesela Bakara sûresinde mü'min, kâfir ve münafik insanların özelliklerinden bahsedildiği gibi... Afakî boyutu, dışarda olan kâfir ve münafik ve mü'min insanların taşıdığı hususiyettir. Enfusî boyutu ise kişinin kendi benliğinde var olan mü'min, kâfir ve münafik özelliklerini görebilmesidir.

Bizim davranışlarımız, sözlerimiz, dünya ve insanları değerlendirmemiz içinde bulunduğumuz mertebe ve makama göredir. Bundan dolayı herkes, aleme kendi görüş dairesinden bakmaktadır. Zira mavi cam , güneşi mavi gösterir; kızıl cam kızıl. Ne zaman camlar renkten kurtulur, işte o zaman güneş beyaz görünür. Renksizlik rengi olan beyaz bütün renklerin hakikati olduğundan diğer renklerden daha doğru gösterir (Mevlânâ, 1993: I, b. 2393). Yani, hayat bakış açılarımıza göre değerlendiririz. Dolayısıyla kibir, ucub, riya, hased, hırs, kıskançlık, şan, şöhret olma sevgisi, sui-zan gibi algılarımızı yanıltan hastalıkları tedavi etmemiz gerekmektir. Aksi takdirde hakikati görebilmede gözlüklerimiz hep renkli olmaya mahkûm olacaktır. Bir başka deyişle İslâm ahlakında yetkinleştiğimizde bizi sağlıklı bakış açılarına kavuşturacak renksizlik gözlüğüne sahip olmamız mümkün olacaktır. Bunun yolu da hakiki olan ilahi sevgiyi gönlümüzde merkeze alarak büyütebilmekten geçer, ancak gönül alemimizde mecazî sevgiler merkezdeyken bu nasıl mümkün olacaktır.? Nitekim "Bizim yolumuzda 
mücadele edenlere biz yolumuzu açarız." (Ankebût, 29/69) âyeti bize yol göstermektedir. Dolayısıyla kişinin içinde bulunduğu durumun farkındalığı içinde, istekle yola koyulması esas olandır. Hedefe varmaktan ziyade tekâmül potası içinde bulunabilmek önemli olandır.

\section{Sonuç}

Kehf suresi sıra dışı hadiselerin yer aldığı bir suredir. Bu hadiselerden biri de $\mathrm{Hz}$. Musa ve Hızır'ın anlatıldığı kıssadır. Düz mantıkla baktığımızda ilk anda anlam veremediğimiz olaylar söz konusudur. Ancak tetkik edildiğinde kâinat ve insan arası oluşumda dengeyi sağlayacak bir mantık silsilesi olduğu ortaya çıkmaktadır. Hadiselere suret ve mana sarmalı açısından bakıldığında paradoks gibi gözüken hadiselerin aslında öyle olmadığı görülmektedir. Zira suret ve mana arasındaki zıtlık Allah'ın kâinata koyduğu bir yasanın göstergesinden ibarettir. Bu da imtihanın bir gereği olarak tezahür etmektedir.

Diğer taraftan Salih kul Hızır mıdır? Hızır kimdir? Onun sahip olduğu ilim, ledün ilim midir veya nasıl bir ilimdir? gibi hususlarda pek çok değerlendirmeler yapılmıştı. Dolayısıyla o konuları tekrar ele almadık. Kıssanın vurgulamak istediği birçok mana olduğunu görmekteyiz. Bu konuda da pek çok çalışma yapılmıştır. Biz de ' bu kıssanın bizim hayatımıza ne gibi bir katkısı olabilir?' sorusundan hareketle bir makalenin sınırları içerisinde muhtemel manaları ortaya koymaya çalıştk.

Değindiğimiz temel noktalar şunlardır: Hz Musa'nın Hızırla buluşması başlı başına önemli bir konudur. Biz sadece o buluşmanın bir yönüne dikkat çekmek istedik; Kevni intiyaç ilkesine binaen Allah'ın Hızır'ı göndermesi Hz. Musa'ya intiyacı olan ilmin kendisine ilka edilmesini sağlamak içindir. Mevlana'nın karşısına Şemsin çıkması gibi... Dolayısıyla bu ilkeyi Allah'ın kâinata koyduğu bir ilke olarak kabul ettiğimizde aynı süreç bizim için de geçerli olacaktır. Yani manevi açıdan kendimizi besleyip ve hazır olduğumuzda Allah sebepler dairesinde Hızır misali, Şems misali bize destek olacak rehberlik yapacak ve bizim hayatımızda dönüşüm sağlayacak insanları gönderecektir. Bu noktada; sabırlı olmak, kıssada temel şartlar arasında zikredilmektedir. Ayrıca manevi açıdan bazı istidatlarımızın gelişme sürecine kadar, teslimiyetle soru sormadan hadiseleri izlemek de bize bir düstur olarak verilmiştir.

Yolculuk başladıktan sonra yaşanan olaylara baktı̆ımızda; geminin delinmesi, Hz. Musa'nın buna tepki göstermesi... Sonrasında Hızır'ın açıklamaları, suretle mananın aynı olmadığını bize göstermiş ve hayatı anlamlandırmamızda bir ışık tutmuştur. Hiçbir şey göründüğü gibi değildir. Suret mananın önünde bir perdedir. Allah herkese çeşitli nimetler vermiştir. Tarih boyunca tecrübe edilmiştir ki, bu nimetlerin her daim sayısız düşmanları olmuştur. Bu düşmanlara karşı nasıl bir savunma stratejisi geliştirmemiz gerekiyor? işte bu hususta bu 
hadise bize bir taktik göstermiştir. Bu taktik, kusurumuzu nazara vererek karşı tarafin gıbta damarını, kıskançlık, hased duygularını tahrik etmemektir. İnsanın kendini kusurlu göstermesi kişinin kendine varlık vermemesiyle alakalı konulara kadar gider ve önemli bir konudur.

Kıssadaki daha derin bir tefekkür gerektiren ikinci ve üçüncü hadiselere baktığımızda "çocuğun ölümü, karşılıksız bir duvarın örülmesi...". Biz bu hadiselere kader cihetiyle ele almak suretiyle açıklık kazandırmaya çalıştık. Kevnî adalet ilkesi de bu anlamda hayatımızın bütününde geçerli olan bir ilkedir. Hadiseleri okurken bu ilke bize rehberlik edecektir. Bu değerlendirmeler ilk etapta zahiri manadan anlaşılanlardan hareketle yapılan çıkarımlardır. Bir de bu manaların alt manalarına dair bazı ariflerin görüşleri ele alınmıştır. Çocuğun öldürülme hadisesinin enfüsi planda kişideki makam sevgisinin ölmesini temsil etmesi gibi. Dolayısıyla ayetleri afakî boyutuyla tefekkür ederken, enfusî boyutuyla da bizim şahsiyet oluşumumuza sağlayacağı katkıları göz önünde bulundurmak önem arz etmektedir.

Bir diğer husus da insan psikolojisi açısından bu kıssanın önemli bir noktaya vurgu yaptğını düşünmekteyiz. Bu üç olayın Hz. Musa'nın, önceden yaşadığı olaylara karşıık gelmesi ve dolayısıyla Hızır'a karşı daha ziyade tepki vermesi oldukça anlamlıdır. Zira Hz. Musa'nın bilinçaltında yer alan olumsuzluklarla yüzleştirilmek suretiyle tedavi edildiğini düşündürmektedir. Bu hususta kıssa insanda kilitlenen noktaları çözümlemede psikoloji bilimine önemli bir bakış açısı kazandırabilir.

Mevlânâ'ya göre Kevnî intiyaç ilkesi; âlemde elde edilecek her şeyin bir intiyaca binaen verilmesi şeklinde, Allah'ın âleme koyduğu bir sünnetullahtır. Allah, varlık sahnesinde yarattı̆ı her şeyi, ihtiyaç sahipleri için yaratmıştı. Dolayısıyla bir şeye sahip olabilmenin öncelikli şart o şeye ihtiyaç hissetmektir. Ona göre İhtiyaç, insanın ne olacağını belirleyen bir ölçüdür. Allah'ın âleme koyduğu her bir nimetten faydalanması, kişinin ihtiyacı ölçüsünde olduğu gibi, kişinin manevi tekâmülü de o kemal düzeyine ihtiyaç duymasıyla mümkün olacaktr. Yani benliğinde bir şeyin ihtiyacını hisseden kişinin o intiyaca yönelik motivasyonu ihtiyaç duyduğu şeyi, varlık sahnesine çıkararak ona sahip olmasını sağlayacaktır (Küçük, 2009: 326-34).

Mevlânâ da bu hususta Mesnevîsine başlarken "Bişnev" diyerek başlar. Talebelerinden istediği en önemli şey, dinlemeleridir. Önce dinlemeyi öğrenmek. Ta ki konuşma istidadı kazanıncaya kadar. Çünkü kişi konuşma istidadı kazanmadan konuşmaya çalışırsa hiçbir zaman konuşamayacaktır. Mevlânâ bunu yeni doğan bir bebek üzerinden örneklendirir:

"Yeni doğan bir bebek, evvela süt içer, bir zaman susup bütünüyle kulak kesilir. Söz söylemeyi öğreninceye kadar söze karşı dudağını yumması lazımdır. 
Şayet kulak vermez, dinlemeden konuşmaya çalışırsa"ti ,ti "eder durur; cihanda kendini dilsiz bırakır. Anadan doğma sağır olan bir kimse hiç( kulak kesilip) dinlemediği için (aynı zamanda) dilsiz olur; (hiç söz işitmemiş olan) nasıl dile gelip konuşsun? Mademki konuşmak için evvela dinlemek gerekiyor. O halde söz tarafina evvela kulak yolundan gel.". (Mesnevî, I, b.1621-7). Maneviyatta da bu işler böyle olmaktadır. Yani bir bebeğin konuşma istidadı gelişinceye kadar dinleyip susmasının gerekliliği gibi maneviyatta da konuşmak için hazır oluşluk halini elde edene kadar soru sormadan susmak gerekmektedir.

Bu konuyu örneklendirme sadedinde, Jung'un bir hastasıyla ilgili görüşlerini aktarmak istiyoruz. "... son derece genç bir adamdı. Tıp kitaplarında hastaı̆ğı ile ilgili konuyu bilinçli bir şekilde özenlice araştırmış ve nevrozuna yardımcı olacak bir çözümleme oluşturmuştu. Düşüncelerinin sonuçlarını, titizlikle kaleme alınmış -neredeyse basılmaya hazır- bir biçimde bana getirdi. Yazdıklarını okumamı ve edindiği bilimsel bilgilere göre iyileşmesi gerekirken niçin hâlâ iyileşmediğini açıklamamı istedi. Getirdiklerini okuduktan sonra, nevrozun nedensel yapısını tanımakla hastalığı iyileştirmek mümkün olsaydı kendisinin de sıkıntılarından tümüyle kurtulmuş olması gerekeceğini söylemek zorunda kaldım. Eğer yakındığı sıkıntılardan kurtulamamışsa bunun nedenini, yaşamı içindeki genel davranışlarını içeren ve hastalık nedenlerinin sınırında yer alan bazı hatalarda aramak gerekiyordu. Genç adamın geçmişinden kışlarını Saint-Maritz ve Nice'de geçirdiğini öğrenmiştim; tatil parasını nereden sağladığını sorduğumda ortaya, kendisini seven ve gerekli parayı günlük yiyeceğinden kısarak biriktiren yoksul bir öğretmen hanım çıkti. Nevrozunun nedeni bu ahlâk dışı davranışında yatiyordu; ayrıca bilimsel açıklamanın bu olguda neden etkisiz kaldığını ortaya koyuyordu... Insan maddi ve manevi açıdan bir bütün olarak ele alınması gereken bir varlıktir." (Jung, 2001: 34-36). Bu örnek de bize göstermektedir ki hadiseleri sadece zahirî sebeplere göre değil, zaman diliminden dolayı bizim fark etmekte zorlandığımız arka plandaki sebeplerinin de olabileceğidir. İşte bu noktada, sebebler zincirini takip ettiğimizde kaderde adaletsizlik söz konusu değildir denilebilir.

Bu konuda Carl Gustav Jung da kehf sûresini değerlendirirken kıssaların mantıksal bir düzlemde gerçekleşmediğine vurgu yapmaktadır.

\section{Notlar}

$\left(^{*}\right) \quad$ Dr. Öğr. Ü., Eskişehir Osmangazi Üniversitesi.

E-posta: sevimyilma@yahoo.com

1 Mevlânâ'ya göre Kevnî ihtiyaç ilkesi; âlemde elde edilecek her şeyin bir ihtiyaca binaen verilmesi şeklinde, Allah'ın âleme koyduğu bir sünnetullahtır. Allah, varlık sahnesinde yarattı̆ı her şeyi, ihtiyaç sahipleri için yaratmıştır. Dolayısıyla bir şeye sahip olabilmenin öncelikli şart o şeye ihtiyaç hissetmektir. Ona göre İhtiyaç, insanın ne olacağını belirle- 
yen bir ölçüdür. Allah'ın âleme koyduğu her bir nimetten faydalanması, kişinin ihtiyacı ölçüsünde olduğu gibi, kişinin manevi tekâmülü de o kemal düzeyine ihtiyaç duymasıyla mümkün olacaktır. Yani benliğinde bir şeyin ihtiyacını hisseden kişinin o ihtiyaca yönelik motivasyonu ihtiyaç duyduğu şeyi, varlık sahnesine çıkararak ona sahip olmasını sağlayacaktır (Küçük, 2009: 326-34).

Mevlânâ da bu hususta Mesnevîsine başlarken "Bişnev" diyerek başlar. Talebelerinden istediği en önemli şey, dinlemeleridir. Önce dinlemeyi öğrenmek. Ta ki konuşma istidadı kazanıncaya kadar. Çünkü kişi konuşma istidadı kazanmadan konuşmaya çalışırsa hiçbir zaman konuşamayacaktır. Mevlânâ bunu yeni doğan bir bebek üzerinden örneklendirir:

"Yeni doğan bir bebek, evvela süt içer, bir zaman susup bütünüyle kulak kesilir. Söz söylemeyi öğreninceye kadar söze karşı dudağını yumması lazımdır. Şayet kulak vermez, dinlemeden konuşmaya çalışırsa"ti ,ti "eder durur; cihanda kendini dilsiz bırakır. Anadan doğma sağır olan bir kimse hiç( kulak kesilip) dinlemediği için (aynı zamanda) dilsiz olur; (hiç söz işitmemiş olan) nasıl dile gelip konuşsun? Mademki konuşmak için evvela dinlemek gerekiyor. O halde söz tarafina evvela kulak yolundan gel.". (Mesnevî, I, b.1621-7). Maneviyatta da bu işler böyle olmaktadır. Yani bir bebeğin konuşma istidadı gelişinceye kadar dinleyip susmasının gerekliliği gibi maneviyatta da konuşmak için hazır oluşluk halini elde edene kadar soru sormadan susmak gerekmektedir.

3 Bu konuyu örneklendirme sadedinde, Jung'un bir hastasıyla ilgili görüşlerini aktarmak istiyoruz. "... son derece genç bir adamdı. Tıp kitaplarında hastalığı ile ilgili konuyu bilinçli bir şekilde özenlice araştırmış ve nevrozuna yardımcı olacak bir çözümleme oluşturmuştu. Düşüncelerinin sonuçlarını, titizlikle kaleme alınmış -neredeyse basılmaya hazır- bir biçimde bana getirdi. Yazdıklarını okumamı ve edindiği bilimsel bilgilere göre iyileşmesi gerekirken niçin hâlâ iyileşmediğini açıklamamı istedi. Getirdiklerini okuduktan sonra, nevrozun nedensel yapısını tanımakla hastalığı iyileştirmek mümkün olsaydı kendisinin de sıkıntılarından tümüyle kurtulmuş olması gerekeceğini söylemek zorunda kaldım. Eğer yakındığı sıkıntılardan kurtulamamışsa bunun nedenini, yaşamı içindeki genel davranışlarını içeren ve hastalık nedenlerinin sınırında yer alan bazı hatalarda aramak gerekiyordu. Genç adamın geçmişinden kışlarını Saint-Maritz ve Nice'de geçirdiğini öğrenmiştim; tatil parasını nereden sağladığını sorduğumda ortaya, kendisini seven ve gerekli parayı günlük yiyeceğinden kısarak biriktiren yoksul bir öğretmen hanım çıkt. Nevrozunun nedeni bu ahlâk dışı davranışında yatiyordu; ayrıca bilimsel açıklamanın bu olguda neden etkisiz kaldığını ortaya koyuyordu... Insan maddi ve manevi açıdan bir bütün olarak ele alınması gereken bir varlıktr." (Jung, 2001: 34-36). Bu örnek de bize göstermektedir ki hadiseleri sadece zahirî sebeplere göre değil, zaman diliminden dolayı bizim fark etmekte zorlandığımız arka plandaki sebeplerinin de olabileceğidir. İşte bu noktada, sebebler zincirini takip ettiğimizde kaderde adaletsizlik söz konusu değildir denilebilir.

4 Bu konuda Carl Gustav Jung da kehf sûresini değerlendirirken kıssaların mantıksal bir düzlemde gerçekleşmediğine vurgu yapmaktadır.

\section{Kaynaklar}

Abdi Rabbih, Seyyid Abdülhâfiz (1972), Buhûs fi Kasasi'I-Kur ân, Beyrut: Dâru'I-Kütübi'I-Lübnâniyye.

Albayrak, İsmail (2003), "Kur'ân ve Tefsir Açısından Hızır Kıssası ve ve Ledün İlmi ", Kur'ân ve Tefsir Araşttrmaları V, İstanbul: ISAV.

Bardakçı, Necmettin (1998), “İsmail Hakkı Bursevî’nin Hz. Musa -Hızır Kıssası Yorumunun illim - Marifet Uygunluğu Açısından Değerlendirilmesi”, S.Ü. Ilahiyat Faültesi Dergisi, sayı: 5. 
Bursevî İsmail Hakkı, Rûhul Beyân fi Tefsiri'I-Ku'ân, İstanbul 1389.

Bursevî, İsmail Hakkı (1997), Kitâbu’n-Netice, (Hazırlayanlar: Ali Namlı- İmdat Yavaş) İstanbul 1997.

Cebecioğlu Ethem (2016), “Niyazi Mısrî̀ye göre Hz. Musa ve Hızır Kıssası: Çocuğun Öldürülmesi", Akademiar Dergi, cilt 1, sayı 1.

Çelebi, ilyas (1998), "Hızır”, DiA, İstanbul: TDV Yayınları.

Isfahânî, Ebü'l-Kâsım Hüseyin b. Muhammed b. Mufaddal er-Rağıb, el-Müfredât fi Ğarîbi'lKur'ân, Mektebetu Nezar Mustafa el-Baz, trs.

İbnü'l-Arabî (2013), Fusûsu'I-Hikem, çev. ve şerh: Ekrem Demirli, İstanbul: Kabalcı Yay.

Jung, Carl Gustav (2015), Dört Arketip, çev. Zehra Aksu Yılmazer, İstanbul: Metis Yay.

Kasaboğlu, Abdurrahman (2006), Carl Gustav Jung'un Kehf Sûresi Tefsiri, Malatya: Mengüceli Yay.

Kaya, Remzi (2002), "Kur'ân Kıssalarının Tefsir ve Teşrîdeki Yeri”, Kur'ân ve Tefsir Araştırmaları c. III.

Kılıç, Sadık (1998), "Kur'ân Kıssalarının Anlam ve Değeri", IV. Kur’ân Haftası, Kur'ân Sempozyumu,17-18 Ocak Ankara 1998.

Kurtubi, Ahmet b. Ebi Bekr (2000), el-Câmiu li Ahkâmi'l-Kur'ân, çev. M. Beşir Eryarsoy, İstanbul.

Kutub, Seyyid b. Kutub b. İbrahim Seyyid (trs.), et-Tasvîru'I-Fenniyyu fi'l-Kur'ân, trs.

Küçük, Osman Nuri (2009), Mevlânâ'ya Göre Manevi Gelişim, İstanbul: İnsan Yay.

Mevlânâ (2000), Divân-ı Kebîr, haz.: A. Gölpınarlı, Ankara: KB Yay.

Mısrî, Niyazi, Risâle-i Hızriyye-i Cedide, Süleymaniye Ktp, Mahmud Efendi Bölümü, no: 3346, vr. 46a-46b.

Mısrî, Niyazî, Risale-i Hızriyye-i Kadim, Süleymaniye Ktp, Mahmud Efendi Bölümü, no: 3346.

Nedvî, Ebu'I-Hasen Ali el-Hüseynî (1954), en-Nübüvvetü ve'I Enbiya, Dâru'I-Kalem.

Ocak, Ahmet Yaşar (1990), İslâm-Türk Inançlarında Hızır Yahut Hızır-ilyas Kültü, Ankara.

Özler, Nurten (2004), Tasavvufta Hızır Telakkisi ve Niyazî Mısrî’nin Hızır Risalesi, (Yayınlanmamış Yüksek Lisans Tezi), İstanbul.

Razi, Fahreddin (1990), Mefâtihu'I Gayb, Beyrut, c. XXI.

Sağlam, Bahaeddin (1985), Kur'ân Kıssaları IIImi ve Edebi Yönleriyle, İstanbul: Tebliğ Yay.

Şengül, İdris (1995), Kur'ân Kıssaları Üzerine, İzmir.

Uludağ, Süleyman (1998), 'Hızır. Tasavvuf ve Halk İnancı', DiA, İstanbul: TDV Yayınları.

Yavuzoğlu, Ergin (2014), İslam Toplumunun İş̧a Sürecinde Kur'ân Kıssalarının Seyri, İstanbul.

Yazır, Elmalılı Muhammed Hamdi, Hak Dini Ku'ân Dini, Eser Neşriyat.

Yılmaz, Sevim (2014), Muhammed ihsan Oğuz ve Tasavvuf Felsefesi, Ankara: Kalem Yay.

Zebidî, Muhammed Murtaza el-Hüseynî (2004), Tâcü'I-Arûs min Cevâhiri'I-Kâmus, et-Türâsü'lArabî, Kuveyt. 